DOI: $10.1515 / \mathrm{rpp}-2017-0015$

Postgraduate Student, YEVHEN BOKHONKO

Khmelnytskyi National University

Address: 11 Instytutska St., Khmelnytskyi, 29016, Ukraine

E-mail: evgenboh@ukr.net

\title{
FOREIGN EXPERIENCE IN TRAINING FUTURE ENGINEERING EDUCATORS FOR MODELING TECHNOLOGICAL PROCESSES
}

\begin{abstract}
The article deals with the study of foreign experience in training engineering educators for modeling technological processes. It has been stated that engineering education is a field that is being dramatically developed taking into account the occurring changes in educational paradigms, global higher education space, national higher education systems, economics, society, etc. It has been indicated that the abundance of the latest information and communication technologies alter the approaches to training various specialists, and, in particular, engineering educators. It has been mentioned that engineering teacher education is undergoing significant development. The activities of the International Society for Engineering Education - IGIP have been justified. It has been found out that there is the vital need for those specialists able to combine the techniques of traditional teaching and innovative scientific achievements, design technical structures, be leader and facilitator of the education process. It has been defined that the activity of the society is aimed at providing engineering educators with relevant training that involves their obtaining the qualification that is accorded with European education standards. US experience in training engineering educators for professional activity has been analyzed. It has been specified that engineering education has become more integrated into the curricula of elementary, middle and high school because of the increasing focus on STEM subjects; the demand for engineering educators is dramatically growing at all the levels of the education system. The peculiarities of engineering educators' training have been demonstrated on the example of the Purdue Polytechnic Institute. It has been concluded that Bachelor of Science in Engineering Technology Teacher Education is a rather interdisciplinary degree program and trains future engineering educators for a wide range of fields. The organization of the program is considerate and well-planned. It has been stated that in Great Britain future engineering educators should be able to apply innovative and less conventional teaching methodology, namely, via problem-based learning, virtual learning environment, etc. According to the mentioned above, the author has outlined the recommendations to improve engineering teacher education in Ukraine.
\end{abstract}

Key words: engineering educator, engineering teacher education, engineering pedagogy, professional training, technological process, foreign experience, the USA, Great Britain.

\section{INTRODUCTION}

Today, engineering education is aimed at providing for a high level of future engineers' technological culture and their compliance with the requirements of postindustrial society, professional mobility, competitiveness on labour market, readiness for self-education and self-improvement. Modern engineering activity is becoming more 
complex and computer-based. It more often has to solve unconventional tasks that require new engineering thinking. Therefore, higher education should contribute to forming modern specialists able to generate fresh ideas and suggest new ways of solving various issues occurring within engineering pedagogy.

The system of engineering teacher education is unique and its very nature makes it possible to form such a harmoniously developed specialist who combines engineering pedagogical skills related to the ability to solve technical problems, systematically think, design technical structures, understand relevant economic issues, cooperate with other people, organize the education process in education institutions, educate young generations, be leader and facilitator.

Undoubtedly, native educators have accumulated vast experience in training future engineering educators and achieved relevant results. At the same time, new times require new ways and ideas, so we believe it necessary to study foreign experience to outline its positive aspects and consequently implement them in the national education system.

\section{THE AIM OF THE STUDY}

The aim of the study consists in the following: 1) to study foreign experience in training future engineering educators, 2) to outline its positive aspects, 3) to produce recommendations as for their creative use within the national education system, and, in particular, engineering teacher education.

\section{THEORETICAL FRAMEWORK AND RESEARCH METHODS}

The problems of engineering and, in particular, engineering teacher education, have been actively studied by native scholars, namely, O. Ihnatiuk (social and humanitarian training of future engineers in the system of forming their professional competency); V. Kuleshova (peculiarities of further engineering teacher education), I. Kuzmichenko (the forming of engineering education content), L. Kyzymenko (engineering teacher training), O. Leshchynskyi (international models of engineering education quality evaluation), Yu. Pazynich (the role of engineering pedagogy in modern education), N. Shemyhon (theoretical aspect in development of future engineering educators' professional motivation), L. Tarhan (theoretical and methodical foundations for forming engineering educators' didactic competency), H. Trishch (training future engineering educators for designing quality management systems), A. Vorokh (experience in implementing active forms and methods of learning in higher engineering education in Ukraine), S. Yakubovska (the problem method in training future research and teaching staff in technical higher education institutions) et al.

In foreign countries different aspects of engineering teacher education have been considered by such scholars as A. A. Abu-aisheh, S. Baine, R. Brent, A. Colby, L. DarlingHammond, A. Delaine, R. Felder, P. Goodhew, J. Hanson, J. Heywood, K. Macatangay, B. Lucas, M. Prince, A. Richert, S. Sheppard, R. Sigamoney, W. Sullivan, R.Tull, M. J. de Vries, Ph. Wankat, D. Williams, Ch. Ch. Yin, et al.

As we can see, engineering education has become the subject of researches by many scholars home and abroad, however, the problem of training future engineering educators for modeling technological processes based on foreign experience with further implementation of their positive aspects in Ukrainian education practice has not been properly investigated yet.

During our study we have used such methods as systematization and generalization, synthesis and analysis, induction and deduction. 
RESULTS

Today, European countries require that teachers of both humanities and technical subjects obtain teacher education. In 1972 in Klagenfurt (Austria) the International Society for Engineering Education (IGIP - Internationale Gesellschaft für Ingenieurpädagogik) was founded. Nowadays, it has the status of an advisory member of UNESCO (International Society for Engineering Education, 2010).

The activities of IGIP are annual international symposia on engineering education; conferences, seminars and workshops organized at both national and international levels; Summer School; information resources; engineering and pedagogical publications; committees dealing with relevant topics of engineering pedagogy. The Society is aimed at ensuring a high level of engineering educators' professional qualifications. Its objectives are: to develop curricula that have practical use and comply with students and employers' needs; to apply multimedia to teaching technical subjects; to integrate learning of humanities and foreign languages in engineering pedagogy; to promote engineers-managers' training; to form knowledge of environment protection; to support engineering education in developing countries.

To carry out the mentioned tasks the executive committee of IGIP founded an international committee of experts - the European Monitoring Committee (EMC) that consists of leading experts working in systems of special technical education and reflects considerate geographical representation of European regions. The executive committee appoints members and chairman of EMC. According to the "Regulations on the National Monitoring Committee", national expert committees at the Presidium of IGIP called National Monitoring Committees (IGIP NMC) are created for implementation and monitoring at the national level. They are represented in eighteen different countries in Europe, Asia and South America. The task of these committees is to provide quality of engineering educators' qualifications. Therefore, they are responsible for the correspondence of engineering educators' qualification level to the national frameworks for both individuals who wish to obtain engineering teacher education and higher education institutions wishing their qualifications to be recognized by IGIP. It must be noted that on September 12, 1999 at the meeting of the European Monitoring Committee (EMC) in Istanbul (Turkey) the National Monitoring Committee of Ukraine (NMCU) was established (International Society for Engineering Education, 2010).

Today, Ukraine has two centers of engineering pedagogy - the Ukrainian Engineering Pedagogical Academy founded in 1999 and beginning from 2009 at Dnipro National Mining University. These centers of retraining and engineering educators' qualification advancement are aimed at training teaching staff for them to become accredited international engineering educators. The education process in the centers is carried out by leading experts in the field of engineering pedagogy, didactics, higher education pedagogy, educational psychology, educational sociology, foreign languages, international law and computer technologies (Пазиніч, Бичко, 2009).

The qualification requirements of the title "International Engineering Educator" (ING-PAED IGIP) is based on three requirements:

1. Good technical knowledge and, therefore, higher technical education and practical experience are obligatory.

2. Knowledge of engineering pedagogy; appropriate training is equal to one term at university ( 240 hours $\min$ ). The content of engineering teacher education should be based on the engineering pedagogy model as well as relevant cycle of disciplines and received in the institutions certified by IGIP. 
3. One year of engineering teaching placements (International Society for Engineering Education, 2010).

It should be mentioned that first and third requirements are simultaneously requirements of FEANI - the European Federation of National Engineering Associations, with which IGIP concluded an agreement on harmonized requirements. Over the years FEANI has been accrediting the programs of engineering schools at higher education institutions across Europe and providing the European Engineer title (EUR-ING). Thus, the International (European) Engineering educator title (ING PAED IGIP) has the following form: engineering qualification + engineering teacher training + engineering teacher practice + practical experience + the command of English, German or French (Пазиніч, Бичко, 2009).

The curriculum of IGIP is a module-based system that includes core modules (7 $\mathrm{CP}$ - credit points), theory modules $(5 \mathrm{CP})$, practice modules $(5 \mathrm{CP})$, elective modules (3 CP).

The core modules include Engineering Education in Theory, Engineering Education in Practice, Laboratory Didactics. The Theory Modules include Psychology, Sociology, Engineering Ethics, Intercultural Competencies. The Practice Modules consist of Presentation and Communication Skills, Scientific Writing, Working with Projects, ICT in Engineering Education. The Elective Modules consist of Evaluation of Student Performance, Quality Management, Portfolio Assessment, Creative Thinking, Coaching and Mentoring in Education, Collaborative Work (International Society for Engineering Education, 2010).

The cooperation between IGIP and FEANI is the most important direction for integration of Ukrainian higher technical education and international professional education systems because it enables technical teachers to obtain the International Engineering educator title, which will contribute to their mobility and competitiveness in global educational space. The Membership in IGIP provides technical teachers with the opportunity to improve their skills in accordance with the requirements of the European model, to obtain access to the results of international researches on the problems of engineering education, to cooperate with colleagues from other countries and share experience, to promote their projects in other countries, to participate in symposiums. So, the establishment of such centers of engineering pedagogy is a significant step in the development of engineering education in Ukraine.

Recently in the USA, engineering education, mainly taught at the postsecondary level, has become more integrated into the curricula of elementary, middle and high school. The increasing focus on engineering education is aimed at promoting STEM subjects that are Science, Technology, Engineering and Mathematics among pupils at an early age. In fact, many educators and educational researchers state that engineering is an ideal basis for skills and concepts of science, technology and mathematics to work together. As a result, apart from being a separate subject, engineering is being incorporated into other STEM subjects to show the material applications of abstract concepts. Taking into consideration the urge to popularize STEM subjects, the demand for engineering teachers is dramatically growing at all the levels of the education system. Indeed, the need for qualified STEM teachers is so remarkable that in $2011,100 \mathrm{Kin} 10$ was founded that is a network including 200 partners which is to train an additional 100,000 qualified STEM teachers by 2021 (To Become a Teacher, 2017; Felder, Brent, 2016). 
For instance, the Purdue Polytechnic Institute (the USA), previously named the College of Technology, is one of 10 colleges at Purdue University offering undergraduate and graduate degrees. The college includes seven academic schools, departments, and divisions: Aviation and Transportation Technology; Engineering Technology; Computer and Information Technology; Computer Graphics Technology; Construction Management Technology; Military Science \& Technology. Within this paper we would like to analyze the peculiarities of Bachelor of Science in Engineering Technology Teacher Education provided by the institute.

This degree program teaches the basics of most technology and engineering concepts, and it enables graduates to teach these concepts to middle school or high school students. Concepts include engineering design, prototyping, architecture and construction, robotics and automation. Students are taught to teach through service learning to help students tackle global challenges. In addition, they obtain a Project Lead The Way preengineering teaching certificate (Purdue Politechnic, 2017).

So, the degree program is divided into eight semesters (a four-year program). During the first of study students are to master such courses as Foundations of Integrated STEM Education; Design Thinking in Technology; Introduction to Educational Technology and Computing; Algebra and Trigonometry; Written Communication Foundation Selective fall semester; Prototyping in Engineering/Technology Education; Technical Graphics Communications; Quantitative Reasoning; Fundamentals of Speech Communication; Humanities - spring semester. The second year of study involves studying the following courses: Exploring Teaching as a Career; Multiculturalism and Education; Educational Policies and Law; Lab Science Foundation Selective; Technical Elective; Free Elective fall semester; Teaching the TE of STEM; Electronic Systems; General Physics; Learning and Motivation; the Inclusive Classrom - spring semester. The third year of study includes Assessment Literacy; Elementary Psychology; Technical Elective; Science Foundation Selective; Free Elective - fall semester; Engineering and Technology Education Instructional Planning and Evaluation; Teaching Design and Innovation I; Reading in the Middle and Secondary Schools: Methods and Problems; Advanced Communication Selective; Technical Elective - spring semester. The final year of study is aimed at mastering such courses as Teaching Design and Innovation II; Engineering/Technology Teacher Lab Planning; Methods of Teaching Engineering/Technology Education; Advanced Communication Selective; Technical Elective - fall semester; Supervised Teaching - spring semester (Purdue Politechnic, 2017).

So, we can make a conclusion that the degree program mentioned above is rather interdisciplinary and trains future engineering educators for a wide range of fields. In our opinion, the organization of the program is considerate and well-planned as during the first yeat of study students get accuainted with the foundations of engineering. The second and third years of study are entirely dedicate mbd to their mastering the principles of teaching. The first part of the fourth year of study prepares students for the supervised teaching they are to undergo in the second semester.

In Great Britain engineering education is mainly based on generic skills and understanding which can be used in a range of employment environments. P. Goodhew believes that the purpose of engineering education is the following:

1) to prepare students for research;

2) to prepare graduates for employment in engineering industry;

3) to prepare engineering/science/numerically literate citizens for society; 
4) to provide an intellectually stimulating education;

5) to teach students to adapt to the changing nature of engineering education (Goodhew, 2010).

According to the UK Subject Benchmark Statement for Engineering, student outcomes include: a) the ability to use knowledge of maths, science and engineering; b) the ability to plan and carry out experiments, as well as to analyze and interpret the obtained data; c) the ability to develop a system, component or process to meet various needs, namely, economic, environmental, social, political, ethical, health and safety, manufacturability and sustainability; d) the ability to work in multidisciplinary teams; e) the ability to define, outline and solve engineering issues; $f$ the understanding of professional and ethical responsibility; g) the ability to effectively communicate; $h$ ) the interdisciplinary education needed to comprehend the influence of engineering solutions in global, economic, environmental and societal contexts; i) the need for life-long learning; j) knowledge of modern issues in engineering education; $\mathrm{k}$ ) the ability to use techniques, skills and modern engineering tools needed in engineering practice (Quality Assurance Agency, 2015).

To achieve these outcomes, future engineering educators should be able to apply more innovative and less conventional teaching methodology. That is why, most undergraduate programs in engineering include a small amount of non-conventional teaching and learning. It is common, in modular programmes, to find a small number of modules delivered via problem-based learning or with varying amounts of active learning. There are also plenty of examples of the use of technology to support student learning, although most of these are at a very elementary level - for example the use of a VLE (virtual learning environment) to store handouts or Powerpoint presentations for later study.

\section{CONCLUSIONS}

So, based on the results obtained we can conclude that engineering education is a field that is being dramatically developed taking into account the occuring changes in educational paradigms, global higher education space, national higher education systems, economics, society, etc. The abundance of the latest information and communication technologies alter the approaches to training various specialists, and, in paricular, engineering educators.

Engineering teacher education is undergoing significant development, too. Thus, the establishment of the International Society for Engineering Education - IGIP proves the vital need for those specialists able to combine the techniques of traditional teaching and innovative scientific achievements, systematically think, design and construct technical structures, cooperate with other people, be leader and facilitator of the education process. The activity of the society is aimed at providing engineering educators with relevant training that involves their obtaining the qualification that is accorded with European education standards. It has been indicated that such training is carried out within centers of engineering pedagogy. It must be noted that there are two such centers in Ukraine already.

In addition, we have studied US experience in training engineering educators for professional activity. It has been found out that engineering education has become more integrated into the curricula of elementary, middle and high school because of the increasing focus on STEM subjects. Moreover, the demand for engineering teachers is dramatically growing at all the levels of the education system. We have demostrated the peculiarities of engineering educators' training on the example of the Purdue Polytechnic Institute. It has been stated that Bachelor of Science in Engineering Technology Teacher Education is a rather interdisciplinary degree program and trains future engineering 
educators for a wide range of field. The organization of the program is considerate and well-planned.

In Great Britain engineering education is maily based on generic skills and understanding which can be used in a range of employment environments. As a result, future engineering educators should be able to apply more innovative and less convetional teaching methodology, namely, via problem-based-learning, virtual learning environment, etc.

According to the mentioned above, we have outlined the following recommendations to improve engineering teacher education in Ukraine:

1) promoting the significance of engineering teacher education among young generations,

2) to effectively study the experience of foreign countries in training modern engineering educators to outline its positive aspects;

3) to organize a close collaboration with IGIF and keep abreast of the latest achievements in implementing study programs for engineering educators;

4) to establish more centers of engineering pedagogy and therefore provide native engineering educators with training that corresponds to European education standards;

5) to enhance the interaction between engineering education and economic center to provide future graduates with further employment.

Rather perspective for further researches we consider the detailed study of European experience in training engineering educators with taking into account the dramatic changes in educational dimension.

\section{REFERENCES}

1. Baine, S. (2013). Teaching Engineering Made Easy 2: Another Friendly Introduction to Engineering Activities for Middle School Teachers. Springfield, OR : Engineering Education Service Center, $192 \mathrm{p}$.

2. Delaine, D. A., Tull, R., Sigamoney, R., Williams, D. N. (2016). Global Diversity and Inclusion in Engineering Education: Developing Platforms toward Global Alignment. International Journal of Engineering Pedagogy, Volume 6, No 1, pp. 56-71.

3. Felder, R. M., Brent, R., Prince, M. J. (2011). Engineering Instructional Development: Programs, Best Practices, and Recommendations. Journal of Engineering Education, Volume 100, No 1, pp. 89-122.

4. Felder, R. M., Brent, R. (2016). Teaching and Learning STEM: a Practical Guide. San Francisco, CA : Jossey-Bass, 336 p.

5. Goodhew, P. (2010). Teaching Engineering All You Need to Know about Engineering Education but Were Afraid to Ask. Liverpool : UK Centre for Materials Education, 203 p.

6. International Society for Engineering Education. (2010). ING PAED IGIP. Retrieved 28.02.2017 from : http://www.igip.org/igip/ing-paed-igip?format=pdf.

7. International Society for Engineering Education. (2010). Modern Engineering Pedagogy Worldwide. Retrieved 28.02.2017 from : http://www.igip.org/igip/.

8. Lucas, B., Hanson, J. (2016). Thinking Like an Engineer: Using Engineering Habits of Mind and Signature Pedagogies to Redesign Engineering Education. International Journal of Engineering Pedagogy, Volume 6, No 2, pp. 4-13. 
9. Quality Assurance Agency. (2015). Subject Benchmark Statement for Engineering. Retrieved 26.02.2017 from : http://www.qaa.ac.uk/en/Publications/Documents/ SBS-engineering-15.pdf.

10. Purdue Politechnic. (2017). Engineering/Technology Teacher Education. Retrieved 2.03.2017 from : https://polytechnic.purdue.edu/degrees/engineering-technologyteacher-education.

11. Purdue Politechnic. (2017). Plan of Study for Engineering/Technology Teacher Education, BS. Retrieved 2.03.2017 from : https://polytechnic.purdue.edu/ degrees/engineering-technology-teacher-education/plan-of-study.

12. Sheppard, S. D., Macatangay, K., Colby, A., Sullivan, W. M. (2008). Educating Engineers: Designing for the Future of the Field. New York : John Wiley \& Sons, $272 \mathrm{p}$.

13. To Become a Teacher. (2017). How to Become an Engineering Teacher. Retrieved 2.03.2017 from : http://tobecomeateacher.org/how-to-become-an-engineering-teacher/.

14. Wankat, Ph. C. (2015). Teaching Engineering. West Lafayette, IN : Purdue education Press, 520 p.

15. Пазиніч, Ю. В., Бичко, О. (2009). Роль інженерної педагогіки в сучасній освіті [The Role of Engineering Pedagogy in Modern Education]. Вісник НТУУ«КПI». Філософія. Психологія. Педагогіка: збірник наукових праиь [Bulletin of National Technical University of Ukraine "Kyiv Polytechnic Institute". Philosophy. Psychology. Pedagogy: the Collection of Scientific Papers], No 3(27), pp. 165-167 (in Ukrainian). 